\title{
Injury Incident Rate Impact toward Adversity Quotient of Female Futsal Athletes
}

\author{
Afianti Sulastri*, Sehabudin Salasa, Upik Rahmi, Yasinta Depki Andriyani \\ Nursing Department, Faculty of Sport and Health Education \\ Universitas Pendidikan Indonesia \\ Bandung, Indonesia \\ *afiantisulastri@upi.edu
}

\begin{abstract}
Adversity Quotient (AQ) is a reflection of personal resilience in facing the problems. In sports, endurance is such an important thing that will enhance the athlete's performance in competition. Injury experience is one factor that can be influencing the athlete's performance. Dealing with that condition, an athlete must keep their motivation high and try to getting well during their recovery process. This research aims to find out the impact of injury rate toward Adversity Quotient belongs to female futsal athlete which conducted by Correlational Study Designs. It was carried out to 30 female futsal athletes in some Indonesian college using a total sampling technique. The data were obtained by using The Adversity Quotient instrument which had been tested for validity $(r=0.391-0.768)$ and reliability (alpha cronbach=0.6). Furthermore, they were analyzed using Pearson product correlation. The results showed that there was a significant negative relationship between the mean of injury frequency towards the AQ of female futsal athletes ( $p$ value= 0.04). The finding shows that the injury experience has an impact on the athletes' AQ. This means it is necessary accompaniment intervention for the athletes during the recovery period, especially from psychological aspect so they can revert to better performance after.
\end{abstract}

Keywords-Adversity Quotient; futsal; female athlete

\section{INTRODUCTION}

Sports activities are one effective way to improve body fitness as well as a means way to make self-actualization. There are some advantages from futsal, besides to get a good physical, also good for mental and social growth [1]. Some of the people's goals playing futsal are to get pleasure, physical fitness and to reach achievement [2]. In the beginning, futsal is adopted from football game which is already existing and popular previously, especially in big cities where there is a lack of space for playing football. Wihandaru noted that there was an increase in people enthusiastic in futsal [3]. This can be shown in the number of the participant on Bekasi Regency Futsal League, from 42 teams in 2017 increased to 47 teams in 2018.

Besides its benefits, futsal also contains a high risk of injury incident for their athletes. Prevalence data of injuries rated in the event of PON XVIII at Central Training DKI Jakarta, from 2009 to 2012 the occurred continued to increase both acute and chronic injuries [4]. The incident, such as muscle injury, ligament tear, or broken bones due to falls or collisions may need a long recovery time, which may show an additional problem like physical or psychological problems to the athlete.

Several cases were noted from the interviews with the six respondents studied. Sometimes, they thought about the recurrent injuries and long recovery time bring them negative impact on their performance consequently. They worried and feared unable to practice and compete, as well as bad physical status resulting a loss of confidence feeling after injury. Negatively, declining in self-confidence also has an impact on decreasing motivation and achievement [5].

Thus, the athlete run into down level of resistance, especially in achieving self-actualization. Personal ability in fighting and facing the obstacles which can deliver them into success is known as Adversity Quotient (AQ) [6]. AQ level can predict a personal response ability about survive or surrender in facing their problems [7].

Several cases were noted from the interviews with the six respondents studied. Sometimes, they thought about the recurrent injuries and long recovery time bring them negative impact on their performance consequently. They worried and feared unable to practice and compete, as well as bad physical status resulting a loss of confidence feeling after injury. Negatively, declining in self-confidence also has an impact on decreasing motivation and achievement [5]. Thus, the athlete run into down level of resistance, especially in achieving selfactualization. Personal ability in fighting and facing the obstacles which can deliver them into success is known as Adversity Quotient (AQ) [6]

AQ level can predict a personal response ability about survive or surrender in facing their problems [7]. Stoltz categorizes individual AQ based on their fighting power into three: quitter, camper, and climber. Quitters are people who choose to go out, avoid obligations, retreat, and stop. This individual's type tend to choose to stop trying; they prefer to ignore and leave. Campers are people who have a little effort then easily satisfied with what they have achieved. This type is usually bored in climbing then looking for a comfortable position and prefer hiding in a friendly situation. Most Campers consider their lives to be successful so that they no longer need to make improvements and effort. Climbers are individuals who make an effort throughout their lives. 
Regardless of background, profit loss, good and bad luck, this type of individuals will continue to strive and struggle [6].

The previous study by Yunus reported the AQ Level of 204 Athletes in Yogyakarta Special Region were include in moderate category on the upper limit (41-80) whose often called Camper [7]. These categories is worn on the people who have insufficient effort and quickly satisfied with their achievement at the moment. One of dominant characteristic of people who called camper is easily bored and always try to get a comfortable position. Most of Campers consider their lives have get successfully so they no need to make improvements and effort sustainably.

This study aims to know a correlation between injury rate incidents toward Adversity Quotient (AQ) of female futsal athlete, generating information that allows practical applications for giving an appropriate action in handling injury and turn back the athlete both physically and mentally into a good performance.

\section{METHODS}

This study performed by using a correlational Study Designs that involving 30 female futsal athletes from various levels which chosen by Total Sampling technique. This research was conducted in two places, first at the Gymnasium UPI which located in Setiabudhi region and second place is in the Sport Hall FPOK located at Cicaheum, Bandung. The data were collected in two months from April to May in 2018 using 30 item of Adversity Quotient questionnaire contains Likert scale. The instrument validity level has rvalue at $0,363-0,752$ and alpha Cronbach value of reliability test $=0,867$. The respondent was ordered to complete the questionnaire directly under permission of the coach. The data then analysed using descriptive analysis for univariate data and correlation Pearson product moment to determine its correlation between two variables, incident of injury toward and the Adversity Quotient level.

\section{RESULTS}

Based on demography data, respondents characteristic can be divided into two categories based on age and joining

TABLE I. DISTRIBUTION INCIDENT OF INJURY $(\mathrm{N}=30)$

\begin{tabular}{|l|l|l|}
\hline \multicolumn{1}{|c|}{ Incident of injury } & \multicolumn{1}{|c|}{ f } & \multicolumn{1}{c|}{$\%$} \\
\hline $0-1$ & 16 & 53,3 \\
$2-3$ & 11 & 36,7 \\
$4-5$ & 3 & 10,0 \\
\hline Total & 30 & 100 \\
\hline
\end{tabular}

TABLE II. ADVERSITY QUOTIENT SCORE OF FEMALE Futsal ATHLETE

\begin{tabular}{|l|l|l|}
\hline \multicolumn{1}{|c|}{ Category } & \multicolumn{1}{c|}{ f } & \multicolumn{1}{c|}{$\%$} \\
\hline Quitter (poor) & 0 & 00,0 \\
\hline Camper (fair) & 18 & 60,0 \\
\hline Climber (good) & 12 & 40,0 \\
\hline Total & 30 & 100,0 \\
\hline
\end{tabular}

Period with the club. This study found that Adversity Quotient level of 16 female futsal athlete $(60 \%)$ are in camper category. Meanwhile the remaining 12 athletes are in climber category $(40,0 \%)$. The result implied that the athletes have an excellent Adversity Quotient level. In other words, the athletes have a good ability in controlling themselves. They are willing not to give up and desperate in facing their obstacles and difficulties.

Table 1 showed the incidence of injuries of the athletes has an average of 2.13 times and the Adversity Quotient score as seen at Table 2, about 91.47. Statistically, there is a significant relationship between the incident rate of injuries towards the Adversity Quotient of athletes, indicated by the $\mathrm{P}$ value of 0.04 $<0.05$. However, the correlation between the two variables is a negative correlation with the Pearson correlation value of 0.507 which means that the higher of the incident rate of injury may impact in reducing the Adversity Quotient of athletes.

\section{DISCUSSION}

Several responses generally arises when the injury occurred, i.e., injury relevant information processing, Emotional upheaval, and reactive behaviour, Identity loss, and isolation. The Athletes will start feeling lonely because of fewer intense in a relationship with their teammates. Social support for them plays crucial role in turning back their motivation. This effort should be made to avoid athletes from excessive fear and anxiety, lack of confidence and declining performance [8].

\section{A. Demographics and Incident Rate of Injuries}

Age become one of a predisposing factor in participating on futsal game. Active athletes are generally between the ages of 17-15 years (50\%). Meanwhile athletes aged 23-25 years are usually have not very active. This is because in the age of 2325 years there has been a decrease in muscle strength and the risk of injury is increasing [9] Another risk factor for injury incident is the exercise program. Generally, the respondents (23 respondents/76.7\%) did the exercises five times in one week. In the training program, respondents were $70 \%$ in the medium category, which is for one hour continuously. In this exercise condition, there was occurred conversion of fatty acids into energy biochemically [10]. The duration of training with the most frequency was 120 minutes which was carried out by 19 respondents $(63.3 \%)$

For a futsal player, having many energy sources will have an impact on functional fitness, giving birth to speed, endurance, muscle endurance, and lung resistance. Fitness or physical fitness can improve the appearance of athletes and reduce the likelihood of injury [11]. This proves that the intensity of exercise that can support good physical abilities and may improve the performance of athletes.

There were 16 respondents $(53.3 \%)$ who had experienced injuries with each frequency of injury between 1 to 5 times. Some injuries to futsal players can occur not always due to physical contact. At this time injury can also be caused by noncontact factors such as fatigue. Physical and mental fatigue can affect an athlete's performance when competing in a competition. One of the causes of physical fatigue occurs due to the distance of one match to another is too short for the standard recovery or recovery time. Research from Gregory 
Dupont of Lille University and Celtic Lab shows that to play two matches with an interlude of 3 to 4 days for recovery will increase the likelihood of decreased performance and risk of injury.

\section{B. The Correlation between Injury Incident toward Adversity Quotient of Athletes}

The decline in performance can have an impact on the inability to increase the amount of achievement. Otherwise it can increase the number of defeats on athletes. The results showed that there was a negative relationship between the frequency variable of the injury to the Adversity Quotient. This negative relationship means that injury incident can reduce the Adversity Quotient level. An injury is an unavoidable event for athletes that may occur during a match or training, in line with Hermawan study that the $19.4 \%$ of sports injuries in athletes was an ankle injury which affected by external and internal factors [12].

The injury factor is possible to be an influential factor on the athlete's Adversity Quotient. In fact many athletes have stopped their football careers because of injuries. Brazilian stars, Ronaldo, for example, who was forced to retire early due to a knee injury he suffered. Krech reported that the perception of injury prevention and treatment in students when learning only $26.4 \%$ of respondents had a good perception. Lack of knowledge and perception of someone about something will reduce a person's confidence in achieving something [13]. Therefore, if an athlete with low knowledge and perception in handling injury experiences an injury, it can cause demotivation that impact to decrease their Adversity Quotient.

The injury is a common thing in sports. Therefore it is necessary to maximize the preventive and rehabilitative processes so that the injured players can fully recover both physically and psychologically. Preventive injury management needs to be done in a way that everyone involved in futsal sports by giving a good understanding and perception of the handling of sports injuries. Thus, if an injury occurs they understand what they have to do and still optimistic in the future about their recovery and can return to give the best performance.

In addition to providing understanding and forming a good perception in handling sports injuries, it is necessary to conduct methods in managing psychological responses due to injury. According to Kurniawan it necessary for cognitive and behavioural methods for managing stress and pain due to injury [14]. Many risk factor of injuries should be appropriately managed to gain Adversity Quotient of athletes at the Quitter level or high, which expected followed by good achievement indeed.

\section{CONCLUSION}

The results found that the level of Adversity Quotient of female futsal athletes is mostly in the Camper or medium category. These can be influenced by injury incident rate that experienced by athletes and the role of their trainer that has not been maximized in assessing the psychological aspects of the athlete during training and competing. There is a negative relationship between the incidents of injury toward Adversity Quotient of athletes. Lack of understanding and perception in handling injury may reduce their performance.

\section{ACKNOWLEDGMENT}

The author thanks, Nursing Department of Faculty of Sport and Health Education, Indonesia University of Education for funding the research

\section{REFERENCES}

[1] G.N. Nazzala, "Hubungan Koordinasi, Keseimbangan, dan Power Otot," 2016 [Online] Retrieved online: http://www.journal.studentuny.ac.id>ojs>download Accessed on March 11 st 2018

[2] Giriwijoyo, dkk. Ilmu Faal Olahraga. Bandung: Jurusan PKO, FPOK, Universitas Pendidikan Indonesia, 2007.

[3] Y. Wihandaru, Respon Psikologi Pada Atlet Futsal Yang Mengalami Cedera ACL. (Skripsi, unpublished). Yogyakarta: Universitas Islam Sunan Kalijaga, 2017.

[4] Junaidi, "Cedera Olahraga Pada Atlet Pelatda PON XVIII DKI Jakarta," Jurnal Fisioterapi, vol. 13, no. 1, 2013

[5] Marom, "Kondisi Psikologis Pemain Futsal yang Pernah Mengalam Cedera dalam Kejuaraan Futsal se-Kabupaten Tubun," Jurnal Kesehatan Olahaga, vol. 02, no. 02, 2014

[6] P.G. Stoltz, Adversity Quotient: Mengubah Hambatan Menjadi Peluang (Translated by T. Hermaya). Jakarta: Grasindo, 2007.

[7] M. Yunus, "Tingkat Adversity Quotient Atlet DIY," Jurnal Psikologi, 2013.

[8] M. Eubank and L. Nicholis, "Psychological Aspects of Coping With Injury," 2001. Retrieved from: http://www.plantationeagles.com/docs/ psychological aspecte of coping with injury.pdf Accessed on Maret 11 st 2018

[9] S.F. Aszahro, Status Daya Tahan Umum, Kekuatan Otot Tingkatan dan Kecepatan Pemain Futsal Putri SMAN 1 Sewon dan SMKN Yogyakarta. (Skripsi, unpublished). Yogyakarta: Universitas Negeri Yogyakarta, 2017.

[10] N.F. Imam, “Latihan Intensitas Sedang,” Jurnal Keolahragaan, 2012. [Online]. Retrieved from: http://journal.eprints.uny.ac.id

[11] W. Dhewangga, "Pengaruh peningkatan intensitas latihan futsal terhadap VO2 Max," 2014. (Skripsi, unpublished). [Online]. Retrieved from: http://eprints.ums.ac.id/32839/12/NASKAH\%20PUBLIKASI.pdf

[12] A. Hermawan, Persentase Cedera Olehraga Pada Atlet Sepak Bola Usia di Bawah 12 Tahun dalam Kompetensi Sepak Bola Antar SSB Tingkat Nasional, unpublished. Yogyakarta, Fakultas Ilmu Keolahragaan: Universitas Negri Yogyakarta, 2015

[13] T.N. Huda and A. Mulyana, Pengaruh Adversity Quotient Terhadap Prestasi Akademik Mahasiswa Angkatan 2013. Bandung: Fakultas Psikologi UIN SGD Bandung, pp. 115-132, 2015.

[14] A. Kurniawan, "Metode Kognitif dan Behavioral untuk Mengelola Stres dan Rasa Sakit Akibat Cedera Pada Atlet Bola Basket," Jurnal psikologi dan kesehatan mental, vol. 2, no. (1), pp. 63-76, 2017. 